\section{Literature Review: Pendidikan kesehatan melalui diskusi kelompok dan curah pendapat terhadap pengetahuan dan sikap Pasangan Usia Subur (PUS) Akseptor KB AKDR Literature Review: Health education through group discussion and brainstorming on knowledge and attitudes of fertile age couples IUD Acceptors}

\author{
Nazirah $^{1}$, Putri Santy ${ }^{2}$, Nurlaili Ramli ${ }^{3}$, Eva Purwita ${ }^{4}$
}

SAGO: Gizi dan Kesehatan 2020, Vol. 2(1) 87-94 (C) The Author(s) 2020

DOI: http://dx.doi.org/ 10.30867/gikes.v2i1.510 https://ejournal.poltekkesaceh.ac.id/index.php/

Poltekkes Kemenkes Aceh

\begin{abstract}
Background: There has been a decrease in the number of IUD family planning acceptors in the last three years, from $3.69 \%$ in 2016 to 3\% in 2017 and 2018. One factor in the low use of IUD contraceptives is public perception. The way to change people's negative perceptions about the IUD is to provide health education.

Objectives: To review several journals about effect of health education about iud (intrauterine) device uses group discussion and brainstorming on the level of knowledge and attitudes fertile age couples.

Methods: The study is a literature review method based on the articles searched on Google Scholar and PubMed. The keywords used to find articles were using the keywords "Health Education, IUD, Group Discussion, Brainstorming, Knowledge, and Attitudes". The data obtained were compiled, analyzed and concluded by looking for similarities, inequalities providing views, comparing and summarizing.

Results: Literature review shows that there is an effect of health education with the method of group discussion and brainstorming on a person's knowledge and attitudes.

Conclusion: Health education using the group discussion method has more influence on increasing knowledge and attitudes. It is hoped of the health institutions can improve health services by providing information through health education to the public about the benefits of intrauterine contraceptives (IUDs).
\end{abstract}

Keywords:

Attitudes, brainstorming, health education, knowledge

\begin{abstract}
Abstrak
Latar Belakang: Terjadi penurunan jumlah akseptor KB IUD dalam tiga tahun terakhir, dari 3,69\% pada tahun 2016 menjadi 3\% tahun 2017 dan 2018. Salah satu faktor rendahnya pemakaian kontrasepsi IUD adalah persepsi masyarakat. Cara untuk mengubah persepsi negatif masyarakat tentang IUD adalah dengan memberikan pendidikan kesehatan, yaitu melalui metode diskusi kelompok dan curah pendapat.

Tujuan: Untuk melakukan review pada beberapa jurnal mengenai pengaruh pendidikan kesehatan tentang AKDR menggunakan metode diskusi kelompok dan metode curah pendapat terhadap tingkat pengetahuan dan sikap pasangan usia subur (PUS).

\footnotetext{
${ }^{1}$ Prodi Sarjana Terapan Kebidanan Poltekkes Kemenkes Aceh. E-mail: naazirahh066@gmail.com

2 Jurusan Kebidanan Poltekkes Kemenkes Aceh. E-mail: putri.santy_80@ymail.com

${ }^{3}$ Jurusan Kebidanan Poltekkes Kemenkes Aceh. E-mail: nurlaili.ramli@poltekkesaceh.ac.id

${ }^{4}$ Jurusan Kebidanan Poltekkes Kemenkes Aceh. E-mail: Eva.purwita@gmail.com

Penulis Koresponding:

Nurlaili Ramli: Jurusan Kebidanan Politeknik Kesehatan Kemenkes Aceh. Jalan Soekarno-Hatta, Kecamatan Lampeunerut, 23352, Aceh Besar. Aceh,Indonesia. E-mail: nurlaili.ramli@poltekkesaceh.ac.id
} 
Metode: Penelitian ini menggunakan metode literatur review berdasarkan artikel yang dicari pada google scholar dan PubMed. Kata kunci yang digunakan untuk mencari artikel adalah menggunakan kata kunci "pendidikan kesehatan, AKDR, diskusi kelompok, curah pendapat, pengetahuan, dan sikap". Data yang diperoleh dilakukan kompilasi, dianalisis dan disimpulkan dengan cara mencari kesamaan, ketidaksamaan memberikan pandangan, membandingkan dan meringkas.

Hasil: Literature review menunjukkan bahwa adanya pengaruh pendidikan kesehatan dengan metode diskusi kelompok dan curah pendapat terhadap pengetahuan dan sikap seseorang.

Kesimpulan: Pendidikan kesehatan menggunakan metode diskusi kelompok lebih berpengaruh terhadap peningkatan pengetahuan dan sikap. Saran, untuk dapat meningkatkan pelayanan kesehatan dengan memberikan informasi melalui pendidikan kesehatan tentang keuntungan alat kontrasepsi dalam rahim (AKDR).

\section{Kata Kunci}

Pendidikan kesehatan, pengetahuan, sikap

\section{Pendahuluan}

$\mathrm{P}$ emerintah Indonesia telah menggalakkan Metode Kontrasepsi Jangka Panjang (MKJP) lebih dari 10 tahun yang lalu namun hingga saat ini MKJP masih belum menjadi pilihan mayoritas pasangan usia subur di Indonesia. Tahun 2015 pemerintah sudah menggalakkan program kontrasepsi pasca salin dan mempunyai angka keberhasilan sebesar $11,99 \%$ dan pada tahun 2016 guna mensukseskan kembali program $K B$, khususnya untuk meningkatkan cakupan MKJP IUD (Metode Kontrasepsi Jangka Panjang) maka pelayanan MKJP IUD dibiayai oleh pemerintah. Pemerintah melalui BPJS (Badan Penyelenggara Jaminan Sosial) memberikan layanan kontrasepsi gratis bagi seluruh rakyat Indonesia, terutama penggunaan kontrasepsi IUD, dengan harapan dapat meningkatkan minat dan cakupan MKJP IUD yang sangat rendah dan terus menurun (BKKBN, 2018).

Penggunaan kontrasepsi MKJP lebih rendah dibandingkan dengan penggunaan kontrasespsi hormonal. Akseptor KB IUD dan implant di Indonesia pada tahun 2019 adalah sebesar 7,4 \% sedangkan di Provinsi Aceh, pengguna kontrasepsi IUD adalah sebesar 3,5\% dan implant sebesar 3 \% (Kementerian Kesehatan, 2019).

Beberapa faktor yang menyebabkan rendahnya pemakaian kontrasepsi IUD yaitu pengalaman, rasa takut terhadap efek samping penggunaan IUD, biaya mahal, prosedur yang rumit, pengaruh dan pengalaman akseptor lain, sosial ekonomi, serta persepsi yang salah tentang IUD, yaitu bahwa kontrasepsi IUD dapat berpindah-pindah tempat sendiri, IUD dapat menyebabkan tumor pada rahim, IUD dapat menyebabkan gangguan pada siklus menstruasi, dan IUD dapat menyebabkan hubungan seksual tidak nyaman. Salah satu cara yang dapat digunakan dalam mengubah persepsi negatif masyarakat tentang IUD adalah dengan memberikan pendidikan kesehatan (Wahyuningrum, 2017).

Pendidikan kesehatan dapat dilakukan dengan beberapa metode, antara lain dengan metode diskusi kelompok dan curah pendapat. Metode diskusi kelompok dapat digunakan untuk penyampaian informasi dengan lebih memberikan kesempatan pada responden untuk mengumpulkan pendapat, membuat kesimpulan atau menyusun berbagai alternatif (Ardilla et al., 2015). Sedangkan metode brainstorming/curah pendapat memungkinkan pemecahan masalah berdasarkan ide-ide yang disampaikan oleh peserta sehingga terjadi diskusi dan pertukaran pendapat dan dapat meningkatkan pengetahuan peserta serta peserta tidak merasa digurui dan diberi penjelasan saja (Fauziningtyas et al., 2018).

Penelitian tentang Pengaruh pendidikan kesehatan terhadap tingkat pengetahuan tentang profil KB IUD pada ibu primigravida di Wilayah Kerja Puskesmas Donorojo Pacitan, menunjukkan bahwa terdapat pengaruh yang signifikan antara pendidikan kesehatan tentang profil KB IUD terhadap tingkat pengetahuan ibu primigravida di wilayah kerja puskesmas donorojo pacitan dengan $p$-value sebesar 0,000 (Wahyuningrum, 2017). Penelitian di Kecamatan Sungai Bahar menunjukkan bahwa semakin tinggi pengetahuan dan sikap positif ibu terhadap penggunaan AKDR maka makin tinggi ibu untuk memilih menggunakan alat kontrasepsi AKDR (Murtiyarini, 2015). Pengetahuan yang baik tentang KB yang dimiliki oleh Akseptor KB menyebabkan keikutsertaan ibu menjadi Akseptor KB menjadi lebih tinggi (Saragih, 2019).

Hal ini menarik perhatian penulis untuk melakukan literature review tentang "pendidikan 
kesehatan menggunakan metode diskusi kelompok dan curah pendapat terhadap tingkat pengetahuan dan sikap pasangan usia subur (PUS)".

\section{Metode}

Jenis penelitian ini merupakan studi literature review dengan menggunakan data primer berdasarkan artikel pada google scholar dan PubMed.

Kata kunci yang digunakan untuk mencari artikel adalah menggunakan kata kunci "pendidikan kesehatan, AKDR, diskusi kelompok, curah pendapat, pengetahuan, dan sikap". Pencarian melalui pubmed didapatkan 5 buah artikel dan di google scholar terdapat 40 buah artikel, sehingga keseluruhan artikel yang didapat berjumlah 45 buah. Artikel dipilih sesuai dengan kriteria inklusi dan eksklusi.
Kriteria inklusi dalam penelitian ini adalah menggunakan artikel terbitan tahun 2014-2020 menggunakan bahasa Indonesia dan Inggris, jenis artikel penelitian merupakan original artikel dengan tema pengaruh pendidikan kesehatan tentang AKDR menggunakan metode diskusi kelompok dan curah pendapat terhadap pengetahuan dan sikap Pasangan Usia Subur (PUS). Adapun Kriteria eksklusi penelitian ini adalah artikel penelitian yang tidak bisa diakses secara full texs secara $p d f$, sehingga hasil screening didapatkan 10 buah artikel, namun artikel yang dapat diakses secara full texs berjumlah 9 buah artikel. Namun dengan mempertimbangkan kriteria inklusi dan eklusi maka artikel yang direview berjumlah 6 buah artikel.

Adapun skema pencarian literature review dapat dilihat pada gambar berikut :

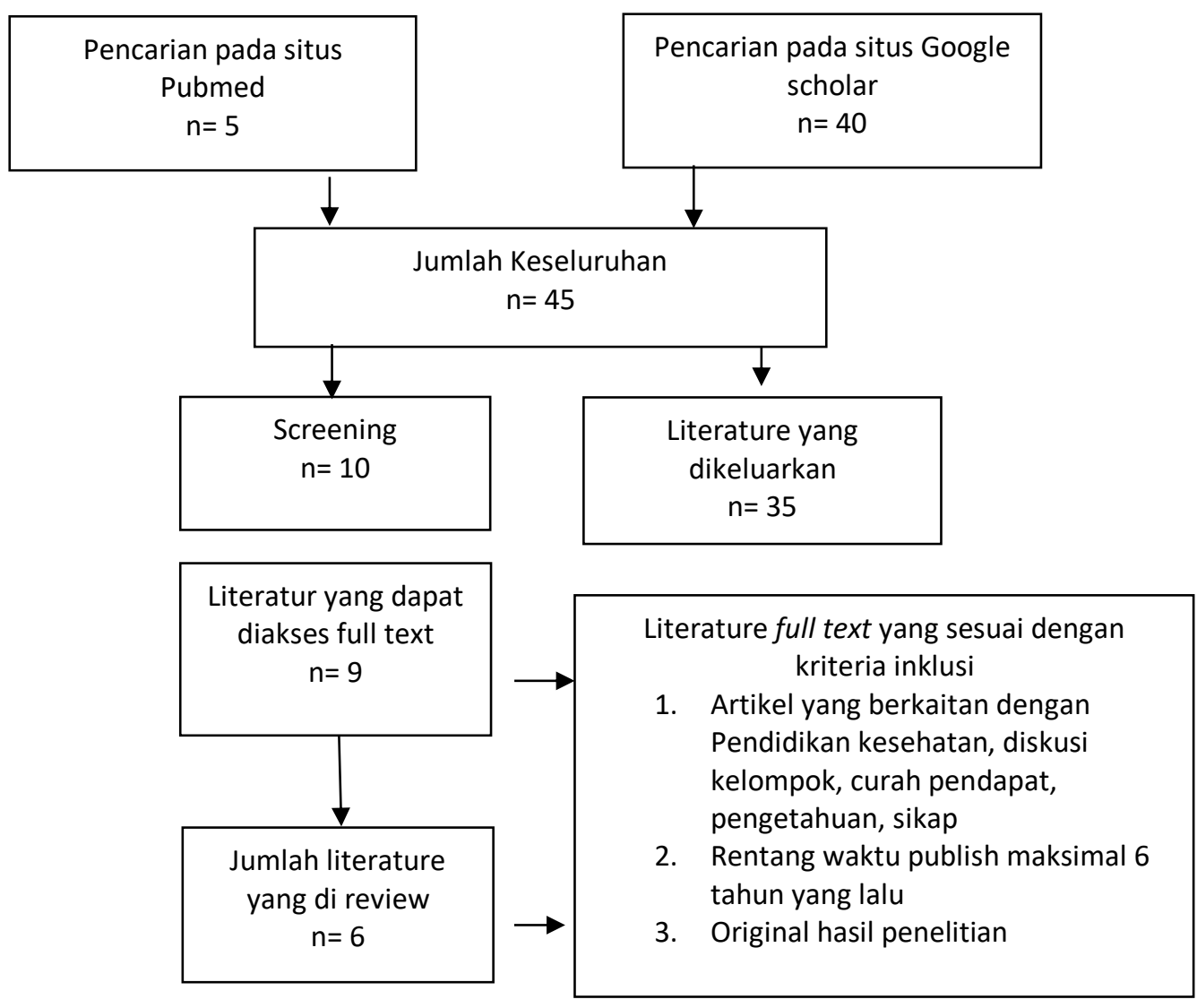

Gambar 1. Alur pencarian literature

\section{Hasil}

Hasil penelusuran diketahui terdapat beberapa literatur yang berkaitan. Adapun artikel yang dilakukan literature review yaitu terdapat 6 artikel yang sangat relevan dengan topik kajian studi ini, sebagaimana disajikan pada tabel 1 . 
Tabel 1. Literature yang dilakukan review

\begin{tabular}{|c|c|c|c|c|}
\hline Peneliti & Judul & Design & $\begin{array}{c}\text { Sampel dan } \\
\text { Teknik Sampling }\end{array}$ & Hasil \\
\hline $\begin{array}{l}\text { (Ebrahimi et al., } \\
\text { 2017) }\end{array}$ & $\begin{array}{l}\text { Effect of Group } \\
\text { Discussion on the } \\
\text { Attitude of Healthcare } \\
\text { Workers Toward the } \\
\text { Patients' Rights: A } \\
\text { Randomized } \\
\text { Controlled Trial }\end{array}$ & Experimental & $\begin{array}{l}\text { Populasi : } \\
\text { semua perawat } \\
\text { yang bekerja di } \\
\text { rumah sakit } \\
\text { shahid madani } \\
\text { di tabriz } \\
\text { Sampel : } 142 \\
\text { orang. Teknik } \\
\text { dilakukan } \\
\text { random }\end{array}$ & $\begin{array}{l}\text { Analisis kovarians menunjukkan perbedaan } \\
\text { yang signifikan secara statistik antara } 2 \\
\text { kelompok dalam skor yang secara signifikan } \\
\text { lebih tinggi pada kelompok intervensi } \\
\text { dibandingkan dengan kelompok kontrol ( } P \\
<0.05 \text { ). Hasil penelitian menunjukkan bahwa } \\
\text { diskusi kelompok dapat meningkatkan } \\
\text { kepatuhan terhadap hak-hak pasien oleh } \\
\text { perawat }\end{array}$ \\
\hline
\end{tabular}

\begin{tabular}{|c|c|c|c|c|}
\hline $\begin{array}{l}\text { Ardan et al., } \\
2019\end{array}$ & $\begin{array}{l}\text { Pengaruh metode } \\
\text { brainstorming } \\
\text { terhadap } \\
\text { pengetahuan dan } \\
\text { sikap tenaga kerja } \\
\text { bongkar muat } \\
\text { tentang HIV dan AIDS } \\
\text { di pelabuhan } \\
\text { gorontalo }\end{array}$ & $\begin{array}{l}\text { Eksperimen } \\
\text { Semu }\end{array}$ & $\begin{array}{l}\text { Populasi : } \\
\text { seluruh anggota } \\
\text { TKBM di } \\
\text { pelabuhan } \\
\text { gorontalo } \\
\text { Sampel : } 20 \\
\text { orang. Teknik } \\
\text { secara purposif }\end{array}$ & $\begin{array}{l}\text { Hasil penelitian menunjukkan bahwa terjadi } \\
\text { peningkatan pengetahuan ( } 28.50 \text { menjadi } \\
\text { 43.05) dan sikap ( } 30.70 \text { menjadi } 43.80) \text {, uji } \\
\text { wilcoxon menunjukkan ada perbedaan } \\
\text { sebelum dan sesudah intrervensi } \\
\text { brainstorming terhadap pengetahuan } \\
(p=0.000) \text { dan sikap ( } p=0.000) \text { TKB tentang } \\
\text { HIV dan AIDS. }\end{array}$ \\
\hline (lis et al., 2019) & $\begin{array}{l}\text { Brainstorming Dalam } \\
\text { Pencegahan } \\
\text { Pneumonia } \\
\text { Pada Anak Balita }\end{array}$ & Case Study & $\begin{array}{l}\text { Populasi : } \\
\text { sebanyak } 194 \\
\text { ibu yang } \\
\text { mempunyai } \\
\text { anak balita } \\
\text { Sampel : } 96 \\
\text { orang melalui } \\
\text { random } \\
\text { proportional }\end{array}$ & $\begin{array}{l}\text { Sebelum diberikan pendidikan kesehatan } \\
\text { pneumonia dengan metode brainstorming } \\
\text { terdapat } 29 \text { responden dengan pengetahuan } \\
\text { cukup (36.8\%) sedangkan pengetahuan } \\
\text { kurang terdapat } 67 \text { responden }(69.8 \%) \text {. } \\
\text { Setelah diberikan intervensi, pengetahuan } \\
\text { meningkat menjadi } 96 \text { responden ( } 100 \%) \\
\text { baik. Hasil uji statistik wilcoxon signed rank } \\
\text { test menunjukkan peningkatan pengetahuan } \\
\text { dengan nil.ai signifikansi } p=0.025 \text { yaitu } p< \\
005 \text {. Variabel sikap juga mengalami } \\
\text { Peningkatan, sebelum diberikan pendidikan } \\
\text { kesehatan dengan metode brainstorming, } \\
\text { responden dengan sikap negatif sebanyak } 62 \\
\text { orang ( } 64.6 \%) \text {, sedangkan responden dengan } \\
\text { sikap positif sebanyak } 34 \text { orang ( } 35.4 \%) \text {, } \\
\text { setelah diberikan intervensi, responden yang } \\
\text { bersikap positif menjadi } 89 \text { orang ( } 92.7 \%) \text {, } \\
\text { sedangkan yang masih memiliki sikap negatif } \\
\text { ada } 7 \text { orang ( } 7.3 \%) \text {. Uji Wilcoxon signed rank } \\
\text { test diketahui nilai } p=0.02 \text { bahwa } p<0.05 \text {. }\end{array}$ \\
\hline (Tarigan, 2015) & $\begin{array}{l}\text { Efektivitas Metode } \\
\text { Ceramah Dan Diskusi } \\
\text { Kelompok } \\
\text { Terhadap } \\
\text { Pengetahuan Dan } \\
\text { Sikap Tentang } \\
\text { Kesehatan } \\
\text { Reproduksi Pada } \\
\text { Remaja Di Yayasan } \\
\text { Pendidikan } \\
\text { Harapan Mekar } \\
\text { Medan }\end{array}$ & $\begin{array}{c}\text { True } \\
\text { Eksperimental }\end{array}$ & $\begin{array}{l}\text { Populasi: } \\
\text { remaja kelas I } \\
\text { dan kelas II } \\
\text { pada Yayasan } \\
\text { Pendidikan } \\
\text { Harapan Mekar } \\
\text { Medan yang } \\
\text { berjumlah } \\
1.350 \\
\text { orang. } \\
\text { Sampel : } 90 \\
\text { orang siswa } \\
\text { melalui random }\end{array}$ & $\begin{array}{l}\text { Hasil penelitian menunjukkan bahwa } \\
\text { perbedaan rata-rata tertinggi skor } \\
\text { pengetahuan (6.30) terjadi pada kelompok } \\
\text { yang diberi penyuluhan dengan metode } \\
\text { diskusi kelompok dengan standar deviasi } \\
2.96 \text {, sedangkan perbedaan rata-rata skor } \\
\text { dalam kelompok penyuluhan dengan metode } \\
\text { ceramah yaitu } 4.03 \text { dengan standar deviasi } \\
2.14 \text {, sedangkan pada variabel sikap, } \\
\text { perlakuan penyuluhan metode diskusi } \\
\text { kelompok menunjukkan skor yang lebih tinggi } \\
\text { dengan peningkatan (13.60) dan standar } \\
\text { deviasi } 7.77 \text { dibandingkan dengan } \\
\text { peningkatan skor kelompok melalui } \\
\text { penyuluhan dengan metode ceramah yang } \\
\text { mencapai } 7.87 \text { dengan standar deviasi } 5.73 \text {. }\end{array}$ \\
\hline
\end{tabular}


Hasil uji ANOVA dan uji T2 Tamhane lebih lanjut menunjukkan bahwa metode diskusi kelompok efektif dalam meningkatkan pengetahuan dan sikap tentang kesehatan reproduksi remaja di Yayasan Pendidikan Harapan Mekar Medan.

\begin{tabular}{llll}
\hline (Ernawat et al., & Pengaruh metode & Quasi & Populasi : 40 \\
2019) & diskusi terhadap & Exsperimental & santriwati \\
& pengetahuan dan & & Sampel : 40 \\
& sikap & orang \\
& Tentang kebersihan & \\
& diri &
\end{tabular}

Berdasarkan hasil penelitian menunjukkan
bahwa responden yang memiliki pengetahuan cukup sebelum intervensi dengan metode diskusi sebanyak 10 orang (25.0\%), pengetahuan kurang sebanyak 30 orang (75.0), setelah diberikan intervensi didapatkan pengetahuan cukup sebanyak 37 orang (92.5\%) dan pengetahuan kurang sebanyak 3 orang $(7.5 \%)$ dan responden yang memiliki sikap positif sebelum intervensi sebanyak 9 orang (22.5\%) sikap negatif sebanyak 31 orang $(77.5 \%)$, setelah diberikan intervensi sikap positif sebanyak 36 orang (90.0\%) dan sikap negatif sebanyak 4 orang (10.0\%), maka dapat disimpulkan bahwa terdapat perbedaan pegetahuan dan sikap sebelum dan sesudah metode diskusi dengan $p$-value $0,000(<0.05)$

\begin{tabular}{|c|c|c|c|c|}
\hline & & & & \\
\hline $\begin{array}{l}\text { (Rilyani et al., } \\
\text { 2019) }\end{array}$ & $\begin{array}{l}\text { Pengaruh Penyuluhan } \\
\text { Penggunaan IUD } \\
\text { Dengan Pengetahuan } \\
\text { Ibu Dalam } \\
\text { Menggunakan Intra } \\
\text { Uterine Device (IUD) }\end{array}$ & $\begin{array}{c}\text { Quasi } \\
\text { Eksperimental }\end{array}$ & $\begin{array}{l}\text { Populasi : } \\
\text { seluruh } \\
\text { pengguna alat } \\
\text { kontrasepsi } \\
\text { sebanyak } 2.288 . \\
\text { Sampel : ibu } \\
\text { yang tidak } \\
\text { menggunakan } \\
\text { IUD sebanyak } \\
96\end{array}$ & $\begin{array}{l}\text { Nilai rata-rata pengetahuan sebelum } \\
\text { diberikan penyuluhan yaitu Mean } 8.15 \mathrm{Std} \text {. } \\
\text { Dev } 2.475 \mathrm{~S} \text {. Eror } 0.253 \text { nilai benar kuisioner } \\
\text { pengetahuan min-max } 4-12 \text {. Nilai rata-rata } \\
\text { sesudah diberikan penyuluhan pada } 96 \\
\text { responden yaitu dengan Mean } 14.83 \mathrm{Std} \text {. Dev } \\
4.898 \mathrm{~S} \text {. Eror } 0.391 \text { nilai benar kuisioner } \\
\text { pengetahuan min-max } 10-17 . \text { Hasil uji statistik } \\
\text { t-tes didapat nilai p-value } 0.000 \text { (<0.05) yang } \\
\text { mana terdapat pengaruh penyuluhan } \\
\text { penggunaan IUD dengan pengetahuan ibu } \\
\text { dalam menggunakan alat kontrasepsi intra } \\
\text { uterine device (IUD) }\end{array}$ \\
\hline
\end{tabular}

\section{Pembahasan}

Terdapat beberapa metode dalam pendidikan kesehatan guna meningkatkan dan membentuk tindakan seseorang diantaranya adalah metode diskusi kelompok dan curah pendapat.

Penelitian yang dilakukan oleh Ernawat et al., 2019 menunjukkan bahwa responden yang memiliki pengetahuan cukup sebelum intervensi dengan metode diskusi sebanyak 10 orang (25.0\%), pengetahuan kurang sebanyak 30 orang (75.0), setelah diberikan intervensi didapatkan pengetahuan cukup sebanyak 37 orang $(92.5 \%)$ dan pengetahuan kurang sebanyak 3 orang $(7.5 \%)$ dan responden yang memiliki sikap positif sebelum intervensi sebanyak 9 orang (22.5\%) sikap negatif sebanyak 31 orang (77.5\%), setelah diberikan intervensi sikap positif sebanyak 36 orang $(90.0 \%)$ dan sikap negatif sebanyak 4 orang $(10.0 \%)$, maka dapat disimpulkan bahwa terdapat perbedaan pegetahuan dan sikap tentang kebersihan diri sebelum dan sesudah metode diskusi dengan $p$ value $0,000(<0.05)$.

Penelitian tersebut diperjelas oleh penelitian lainnya mengenai efektifitas metode ceramah dan diskusi kelompok terhadap pengetahuan dan sikap tentang kesehatan reproduksi remaja yang diperoleh hasil rata-rata tertinggi skor pengetahuan (6.30) terjadi pada kelompok yang diberi penyuluhan dengan metode diskusi kelompok dengan standar deviasi 2.96 , sedangkan perbedaan rata-rata skor dalam kelompok penyuluhan dengan metode ceramah yaitu 4.03 dengan standar deviasi 2.14, sedangkan pada variabel sikap, perlakuan penyuluhan dengan metode diskusi kelompok menunjukkan skor yang lebih tinggi dengan peningkatan (13.60) dan standar deviasi 7.77 dibandingkan dengan peningkatan skor kelompok melalui penyuluhan dengan metode ceramah yang mencapai 7.87 dengan standar deviasi 5.73. Hasil uji 
ANOVA dan uji T2 Tamhane lebih lanjut menunjukkan bahwa metode diskusi kelompok efektif dalam meningkatkan pengetahuan dan sikap tentang kesehatan reproduksi remaja (Tarigan, 2015).

Penelitian tersebut sejalan dengan penelitian lainnya yang juga melakukan penelitian tentang pengaruh metode diskusi kelompok terhadap sikap menunjukkan bahwa metode diskusi dapat memberikan pengaruh signifikan terhadap sikap pekerja pelayanan kesehatan menuju hak pasien yang di peroleh hasil analisis kovarians $(P<0.05)$ yang dapat disimpulkan bahwa diskusi kelompok dapat meningkatkan kepatuhan perawat terhadap hak-hak pasien (Ebrahimi et al., 2017).

Selain metode diskusi kelompok, curah pendapat juga merupakan salah satu metode pendidikan yang dapat dilakukan. Penelitian mengenai pengaruh metode brainstorming terhadap pengetahuan dan sikap tenaga kerja bongkar muat tentang HIV dan AIDS menunjukkan bahwa terdapat perbedaan pengetahuan dan sikap tentang HIV dan AIDS pada tenaga kerja bongkar muat (TKBM) dipelabuhan gorontalo yang signifikan sebelum dan sesudah dilakukan intervensi metode brainstorming (Ardan et al., 2019).

Penelitian tersebut sejalan dengan penelitian lainnya yang menyatakan bahwa pemberian pendidikan kesehatan dengan menggunakan metode brainstorming dapat meningkatkan pengetahuan dan sikap ibu tentang pencegahan pneumonia pada anak balita. Hasil uji statistik dengan menggunakan wilcoxon signed rank test menunjukkan terjadinya peningkatan pengetahuan dengan nilai signifikansi $p=0.025$ yaitu $p<0.05$. Demikian juga variabel sikap mengalami peningkatan dengan nilai $p=0.02$ (lis et al., 2019).

Penelitian tentang pengaruh metode brainstorming terhadap pengetahuan dan sikap tenaga kerja bongkar muat tentang HIV dan AIDS di pelabuhan gorontalo menunjukkan bahwa terdapat perbedaan yang signifikan antara pengetahuan siswa sebelum dan sesudah intervensi tentang HIV dan AIDS dalam kelompok brainstorming (Saputra, 2016). Demikian pula dengan penelitian ibu akseptor KB yang menggunakan alat kontrasepsi intra uterine device (IUD), hasil uji statistik $t$-test menunjukkan bahwa terdapat pengaruh penyuluhan penggunaan IUD dengan pengetahuan ibu dalam menggunakan alat kontrasepsi intra uterine device (IUD). (Rilyani et al., 2019).
Pengetahuan dan sikap merupakan salah satu faktor penyebab terbentuknya perilaku, oleh karenanya pengetahuan masyarakat dapat ditingkatkan melalui upaya pendidikan kesehatan. Pendidikan kesehatan adalah suatu kegiatan atau usaha untuk menyampaikan pesan kesehatan kepada masyarakat, kelompok, atau individu, dengan harapan bahwa dengan adanya pesan tersebut, masyarakat, kelompok atau individu dapat memperoleh pengetahuan tentang kesehatan yang lebih baik (Notoatmojo, 2014).

Terdapat beberapa metode dalam pendidikan kesehatan untuk meningkatkan dan membentuk tindakan seseorang diantaranya adalah metode diskusi kelompok dan curah pendapat. Metode diskusi kelompok merupakan metode yang digunakan untuk menyampaikan informasi dengan lebih memberikan kesempatan pada seseorang untuk mengumpulkan pendapat, membuat kesimpulan atau menyusun berbagai alternatif pemecahan masalah. Sedangkan metode curah pendapat merupakan suatu bentuk diskusi untuk menghimpun gagasan, pendapat, informasi, pengetahuan dan pengalaman dari semua anggota kelompok, metode ini merupakan modifikasi metode diskusi kelompok prinsipnya sama dengan metode diskusi kelompok, namun berbeda saat memulai diskusi. Pemimpin kelompok dalam curah pendapat memancing dengan satu masalah, kemudian tiap peserta memberikan jawabanjawaban atau tanggapan (Hasnidar et al., 2020; J.Bensley \& Brookins- Fisher, 2003). Selain kedua metode tersebut, dibutuhkan media pendidikan kesehatan berupa leaflet untuk meningkatkan pengetahuan pada responden (Masthura et al., 2019)

Media pendidikan dibutuhkan dalam memberikan pendidikan kesehatan agar responden dapat lebih memahami tentang baerbagai informasi terutama informasi alat kontrasepsi AKDR. Namun kesadaran terhadap pentingnya menggunakan alat kontrasepsi serta dukungan suami berperan penting dalam memutuskan menggunakan alat kontrasepsi selain faktor pengetahuan dan sikap ibu sendiri serta dukungan informasi dari petugas kesehatan (Anjum et al., 2014; Setiasih et al., 2016; Yuliasari, 2016)

Peneliti berasumsi bahwa pemberian informasi melalui pedidikan kesehatan dengan menggunakan metode diskusi kelompok dan curah pendapat dapat menambah pengetahuan sehingga akan berdampak pada sikap positif terhadap 
keinginan pasangan usia subur (PUS) untuk menggunakan kontrasepsi AKDR. Penyampaian pendidikan kesehatan dengan menggunakan metode diskusi kelompok dapat lebih memberikan kesempatan pada seseorang untuk mengumpulkan pendapat, membuat kesimpulan atau menyusun berbagai alternatif pemecahan masalah.

Sedangkan metode curah pendapat merupakan modifikasi dari metode diskusi kelompok, setiap anggota dapat mencurahkan pendapatnya dan merangsang anggotanya untuk berpikir aktif dan berbagi informasi serta dapat meningkatkan daya ingat dan melatih peserta agar terlatih berpikir dan meningkatkan konsentrasi. Metode curah pendapat juga dapat meningkatkan percaya diri peserta karena dibutuhkan keberaniaan saat menyampaikan pendapat atau berbicara didepan kalayak ramai/masyarakat.

\section{Kesimpulan}

Pendidikan kesehatan dengan metode diskusi kelompok dan curah pendapat berpengaruh terhadap pengetahuan dan sikap, dimana terdapat perbedaan nilai rata-rata sebelum dan sesudah dilakukan pendidikan kesehatan menggunakan metode diskusi kelompok.

Institusi kesehatan diharapkan dapat meningkatkan pelayanan kesehatan dengan memberikan informasi melalui pendidikan kesehatan kepada masyarakat tentang keuntungan alat kontrasepsi dalam rahim (AKDR).

\section{Deklarasi Konflik Kepentingan}

Penelitian ini tidak menyertakan konflik kepentingan penulis maupun potensi konflik kepentingan instansi sehubungan dengan penelitian yang telah dilakukan, baik berdasarkan kepengarangan, maupun publikasi.

\section{Ucapan Terima Kasih}

Ucapan terimakasih disampaikan kepada Ketua Jurusan Kebidanan Politeknik Kesehatan Kemenkes Aceh, Kaprodi D IV Kebidanan yang telah memberikan kesempatan untuk pelaksanaan penelitian. Selain itu, ucapan terima kasih juga kami sampaikan kepada pembimbing / supervisor yang telah membantu perbaikan baik secara teknis maupun isi dalam pelaksanaan penelitian ini.

\section{Daftar Rujukan}

Anjum, S., Durgawale, P. M., \& Shinde, M. (2014). Knowledge of contraceptives Methods and Appraisal of Health Education among Married Woman. International Journal of Science and Research (IJSR), 3(3), 584-590.

Ardan, M., Muammar, Yunus, R., \& Haimin, F. G. (2019). Pengaruh metode brainstorming terhadap pengetahuan dan sikap tenaga kerja bongkar muat tentang HIV dan AIDS di pelabuhan Gorontalo. Jurnal IImiah Kesehatan Diagnosis, 14(4).

Ardilla, A., Ridha, A., \& Jauhari, A. H. (2015). Efektifitas metode diskusi kelompok dan metode ceramah terhadap peningkatan pengetahuan dan sikap remaja tentang perilaku seks pranikah di SMA negeri 1 bengkayang. Fakultas IImu Kesehatan. Universitas Muhammadiyah Pontianak. Hal 76-91). JuMantik: Jurnal Mahasiswa Dan Penelitian Kesehatan, 2(1), 76-91.

BKKBN. (2018). Kebijkan dan Strategi Akselerasi Program Kependudukan, KB dan Pembangunan Keluarga TA. 2014. BKKBN.

Ebrahimi, H., Jafarabadi, M. A., Arshatnab, H. N., \& Ghasemian, Z. (2017). Effect of Group Discussion on the Attitude of Healthcare Workers Toward the Patients ' Rights: A Randomized Controlled Trial. Crescent Journal of Medical and Biological Sciences, 4(4), 180-185.

Ernawat, Asrina, A., \& Suharni. (2019). Pengaruh metode diskusi terhadap pengetahuan dan sikap Tentang kebersihan diri (Studi Pada Santriwati Pondok Pesantren Darul Abrar). Sinergitas Multidisiplin Ilmu Pengetahuan Dan Teknologi, 2.

Fauziningtyas, R., Diantami, A. Y. M., \& Makhfudli. (2018). Efek metode brainstorming terhadap tingkat pengetahuan dan rasionalitas penggunaan obat swamedikasi. Jurnal Ners LENTERA, 6(1), 55-66.

Hasnidar, Tasnim, Sitorus, S., Mustar, W. H., Fhriwati, Yuliani, M., Marzuki, I., Yunianto, andi E., Susilawaty, A., Puspita, R., Patolla, Effendi Sianturi, \& Sulfianti. (2020). IImu Kesehatan Masyarakat (Cetakan 1). Yayasan 
Kita Menulis.

lis, I., Islaeli, Wahyuni, S., Zoahira, W. O. A., \& Purnamasari, A. (2019). Brainstorming Dalam Pencegahan Pneumonia Pada Anak Balita. HIJP: Health Information Jurnal Penelitian, 11(2), 100-107.

J.Bensley, R., \& Brookins- Fisher, J. (2003). Metode Pendidikan Kesehatan Masyarakat (Apriningsih \& N. S. I. Hippy (eds.); Edisi 2). Penerbit Buku Kedokteran EGC.

Kementerian Kesehatan. (2019). Data dan Informasi : Profil Kesehatan Tahun 2019.

Masthura, R., Yuniwati, C., \& Ramli, N. (2019). Efektivitas lembar balik dan leaflet terhadap pengetahuan ibu hamil tentang pemberian makanan pendamping ASI (MP-ASI). Jurnal SAGO Gizi Dan Kesehatan, 1(1), 9-16.

Murtiyarini, I. (2015). No Title. Jurnal Poltekkes Jambi, XIII(3), 134-140.

Notoatmojo, S. (2014). Ilmu Perilaku Kesehatan. Rineka Cipta.

Rilyani, R., Putri, R. H., \& Lestari, D. (2019). Pengaruh Penyuluhan Penggunaan IUD Dengan Pengetahuan Ibu Dalam Menggunakan Intra Uterine Device (IUD). Holistik Jurnal Kesehatan, 13(1), 48-55.

Saputra, N. (2016). Differences influence of health education hiv/aids with brainstorming method and teaching using audio visual media studies against knowledge senior high school 4 south tangerang. Jurnal Universitas
Muhamadiyah Jakarta, 1(1), 661-665.

Saragih, E. (2019). Faktor-faktor Yang Mempengaruhi Keikutsertaan Ibu Menjadi Akseptor Alat Kontrasepsi Dalam Rahim (AKDR) Di Desa Bonandolok Kecamatan Sijamapolang. Journal of Midwifey Senior, 2(1), 36-42.

Setiasih, S., Widjanarko, B., \& Istiarti, T. (2016). Analisis Faktor-Faktor Yang Mempengaruhi Pemilihan Metode Kontrasepsi Jangka Panjang (Mkip) Pada Wanita Pasangan Usia Subur (Pus) Di Kabupaten Kendal. Jurnal Promosi Kesehatan Indonesia, 11(2), 32-46.

Tarigan, A. P. S. (2015). Efektivitas Metode Ceramah Dan Diskusi Kelompok Terhadap Pengetahuan Dan Sikap Tentang Kesehatan Reproduksi Pada Remaja Di Yayasan Pendidikan Harapan Mekar Medan. Jurnal IImiah PANNMED, 10(2).

Wahyuningrum, M. I. (2017). Pengaruh Pendidikan Kesehatan Terhadap Tingkat Pengetahuan Tentang Profil KB IUD pada ibu primigravida Di Wilayah Kerja Puskesmas Donorojo Pacitan. Universitas Aisyiyah.

Yuliasari, D. (2016). Hubungan antara dukungan suami dan pendapatan keluarga terhadap perilaku pemasangan Alat Kontrasepsi Dalam Rahim (AKDR) di Puskesmas Unit II Yulang Bawang Tahun 2013. Jurnal Kebidanan, 2(2), 60-64. 